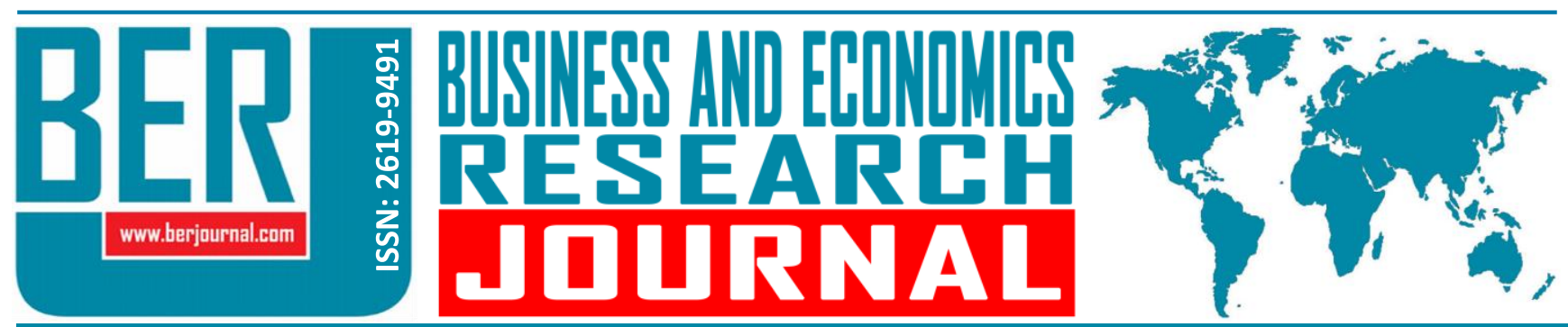

Business and Economics Research Journal Vol. 9, No. 4, 2018, pp. 749-760 doi: 10.20409/berj.2018.136

\title{
Foreign Direct Investment, Trade Openness and Economic Growth: A Panel Data Analysis for Sub-Saharan Africa
}

\author{
Mehmet Cinar ${ }^{\mathrm{a}}$, Ndzembanteh Aboubakary Nulambeh ${ }^{\mathrm{b}}$
}

\begin{abstract}
This paper examines the impact of foreign direct investment and trade openness on economic growth for 34 Sub-Saharan African countries. The methodology involves estimating the augmented endogenous growth model using panel data that runs from 2006 to 2015. The coefficients of the estimated REM model are statistically significant with all the signs compatible as expected. Our findings show that all the variables are significant in explaining SSA growth. Specifically, foreign direct investment and trade openness positively impact growth except inflation with a negative effect on growth. This study will assist the policy makers to increase effort towards the creation of favorable business climate that attract more foreign direct investment to SSA and enhance long term growth.
\end{abstract}

\author{
Keywords: Foreign Direct \\ Investment (FDI), Trade \\ Openness, Economic Growth, \\ SSA, Panel Data \\ JEL: C33, F21, O40, 047 \\ Received : 03 April 2018 \\ Revised : 23 May 2018 \\ Accepted : 16 August 2018 \\ Type : Research
}

\section{Introduction}

Foreign Direct Investment (FDI) has become the most important type of financing in developing countries, especially for Sub-Saharan Africa (SSA). The significance of this external financing is seen in the efforts made by SSA countries to draw FDI into Africa through the development of friendly policies. FDI plays a major role in promoting growth, creating of jobs, transfer of technology and it is fairly steady with less variation compared to portfolio investment.

The role of FDI in stimulating growth is one of the most debatable topics in the growth literature. In the standard Solow growth model, FDI enables the host countries to achieve investment that surpasses their own domestic saving and boosts capital growth. According to this theory, the potential impact of FDI on growth is confined to short run. In the long run, physical capital is subject to the law of diminishing marginal returns, indicating that the recipient country might converge to the steady-state growth.

In recent years, most countries in SSA have been characterized with major progress despite the high level of economic fluctuations. Economists used to wonder whether Africa could ever reach the 21st century without collapsing. In other word, many predicted that Africa might remain the "doomed continent" but most of the countries have witnessed rapid growth in commodity export as well as the non-commodity export. The average annual growth rate for SSA between 2000 and 2015 is about $6.5 \%$. In fact, some of the non-commodity exporting countries such as Burkina Faso, Mali and Rwanda produced faster growth than

a Assoc. Prof., PhD., Bursa Uludag University, Faculty of Economics and Administrative Sciences, Department of Econometrics, Bursa, Turkiye, mcinar@uludag.edu.tr (ORCID ID: 0000-0001-8441-243X)

b PhD. Student, Bursa Uludag University, Faculty of Economics and Administrative Sciences, Department of Economics, Bursa, Turkiye, ndzembanteh10@yahoo.com (ORCID ID: 0000-0002-4039-6690) 
their commodity-exporting neighbors. Even though African countries grow at faster rate, can we say that this growth is capable to improve the life of many Africans?

Ricardo, in his famed theory of comparative advantage, showed that countries benefit from trade by specializing in the production of goods with the lowest opportunity cost. From this theory it is seen that African countries have a comparative advantage in the exports of raw materials especially in agriculture, considered as the backbone of most African economies. This sector needs to be improved in other to boost African productivities. It is suggested that sub-Saharan African countries, especially the resource-based economies, should concentrate in improving productivity in most areas where they have a comparative advantage and on moving up the value chain in those commodities.

One of the primary challenges facing Africa's resource rich economies is how to diversify production beyond the natural resource sector. Natural resource-based products have dominated exports for the past 50 years, but reliance on such products has not made African countries richer and due to this, researchers are wondering whether it is resource curse. In spite of this circumstance, resource-rich countries like Norway, Indonesia and Malaysia have demonstrated that it is possible to use natural resources to diversify and stimulate growth.

The impact of FDI and Trade openness on growth has broadly been studied empirically and theoretically in literature and the results are quite diverse and inconclusive. The findings in this area can be grouped into three categories. Some studies have found a positive relationship; some studies have found a negative relationship. Finally, very few studies have indicated inconclusive. The varied views indicates a literature gab indicate a gap, permitting us to develop more interest to further verify the growth-FDI relationship especially in SSA countries where few studies have been conducted. The paper will add to the existing literature recent data and the relationship between the above variables in multivariate form.

The purpose of this paper is to examine the effect of FDI, Trade Openness, and Inflation on Economic Growth in SSA countries. Our paper is presented as follows. Section II presents review of the literature, Section III discusses sources of data and methodology, and Section IV shows the empirical findings while Section $\mathrm{V}$ concludes the paper.

\section{The Foreign Direct Investments in SSA and Developing Economies}

The global inflow of FDI to SSA shows that West Africa is dominating, Southern Africa coming in the second position and East Africa is lagging behind the other regions see Figure 1 below. Around the 70s, all the regions were experiencing similar trend until the $80 \mathrm{~s}$. The proportion of FDI inflow in gross domestic terms averaged $14 \%$ for SSA as a group compared to $11 \%$ and $17 \%$ for Asia and Latin America, respectively during 2000- 2016. In 1970, FDI inflow to West Africa, Middle Africa and East Africa were approximately 385 million dollars, 31 million dollars, 81 million dollars respectively. In 2014, FDI have increased more significantly to 12,115 billion dollars for West Africa, 10,507 billion dollars for Central Africa and 16,786 billion dollars for East Africa see Table 1 below.

Table 1. FDI to Sub Sahara Africa (SSA, 2000 - 2015) in Billion USD

\begin{tabular}{ccccc}
\hline Year & Eastern Africa & Middle Africa & Southern Africa & Western Africa \\
\hline 2000 & $1,467.54$ & $1,529.23$ & $1,273.14$ & $2,130.94$ \\
\hline 2005 & $2,579.14$ & 803.70 & $7,478.01$ & $7,157.70$ \\
\hline 2009 & $5,500.45$ & $7,453.16$ & $8,374.54$ & $14,725.56$ \\
\hline 2010 & $6,686.24$ & $4,298.06$ & $4,833.66$ & $12,007.61$ \\
\hline 2012 & $14,481.89$ & $1,795.32$ & $6,407.12$ & $16,873.42$ \\
\hline 2013 & $14,766.14$ & 489.14 & $9,651.52$ & $14,493.37$ \\
\hline 2014 & $16,786.12$ & $10,506.97$ & $6,847.25$ & $12,115.28$ \\
\hline 2015 & $13,937.04$ & $14,032.48$ & $3,291.85$ & $9,893.92$ \\
\hline
\end{tabular}

Source: UNCTAD 2017. 
Before 1980s, the ease of doing business in Africa was not favorable. Most of the policies created were hostile in relation to private sector investment owing to the fact that people were afraid of losing the private owned enterprises to foreign firms. This persisted until the middle of 1990 when massive privatization took place. State owned enterprises were transferred to foreign companies even though the strategic sectors like energy, telecommunication and the banking were still in control of the government. All these undoubtedly discouraged the inflow of FDI to Africa. Likewise, African countries were perceived to be risky due to war, corruption, failure of projects, famine and poor governance especially in East Africa characterized with political unrest.

Figure 1. Foreign Direct Investment: Inward and Outward Flows and Stock 1970-2015

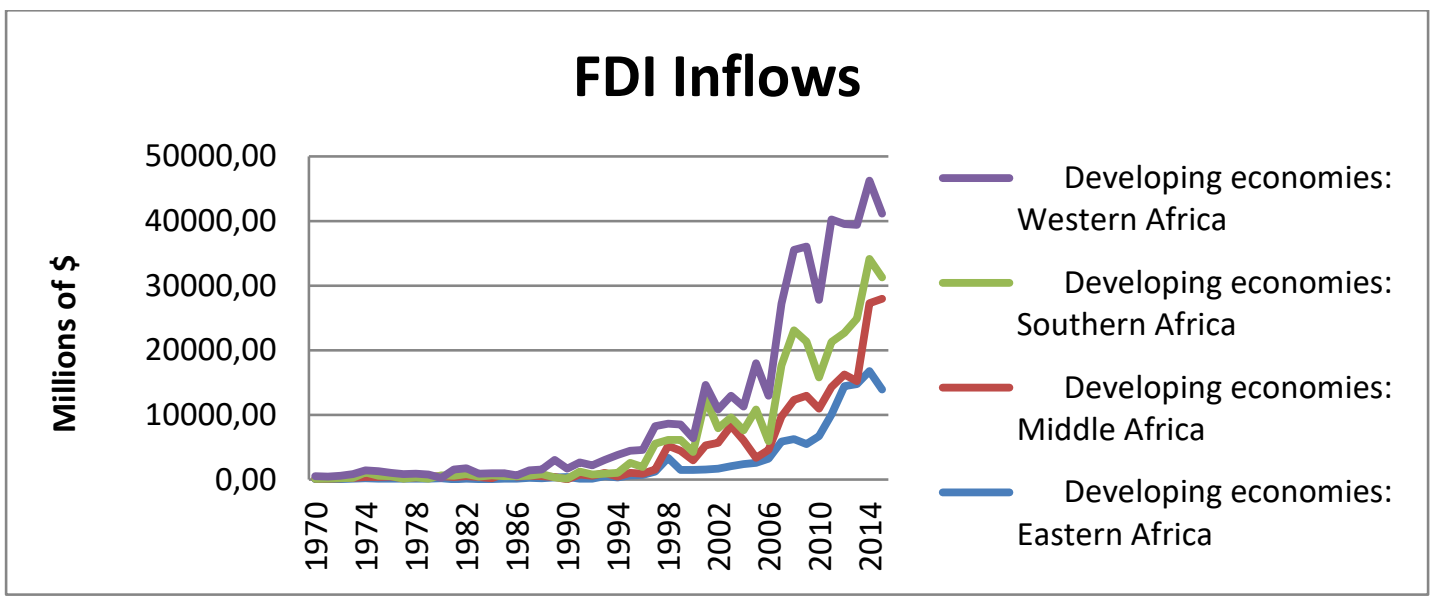

Source: UNCTAD 2017.

Positive measures and economic reform policies were taken to increase the role of private sector to improve the life of many Africans. Many foreign companies have been allowed to settle in Africa with massive privatization of state owned enterprises. The governments also created policies that facilitated foreign direct investment inflows to Africa. This includes the removal of trade barriers, removal of restrictions on repatriation of profits and the liberation of the tax system. All these policies greatly attracted more capital in the form of FDI.

Figure 2. Trends in FDI Inflow into Developing Countries 1970 - 2015

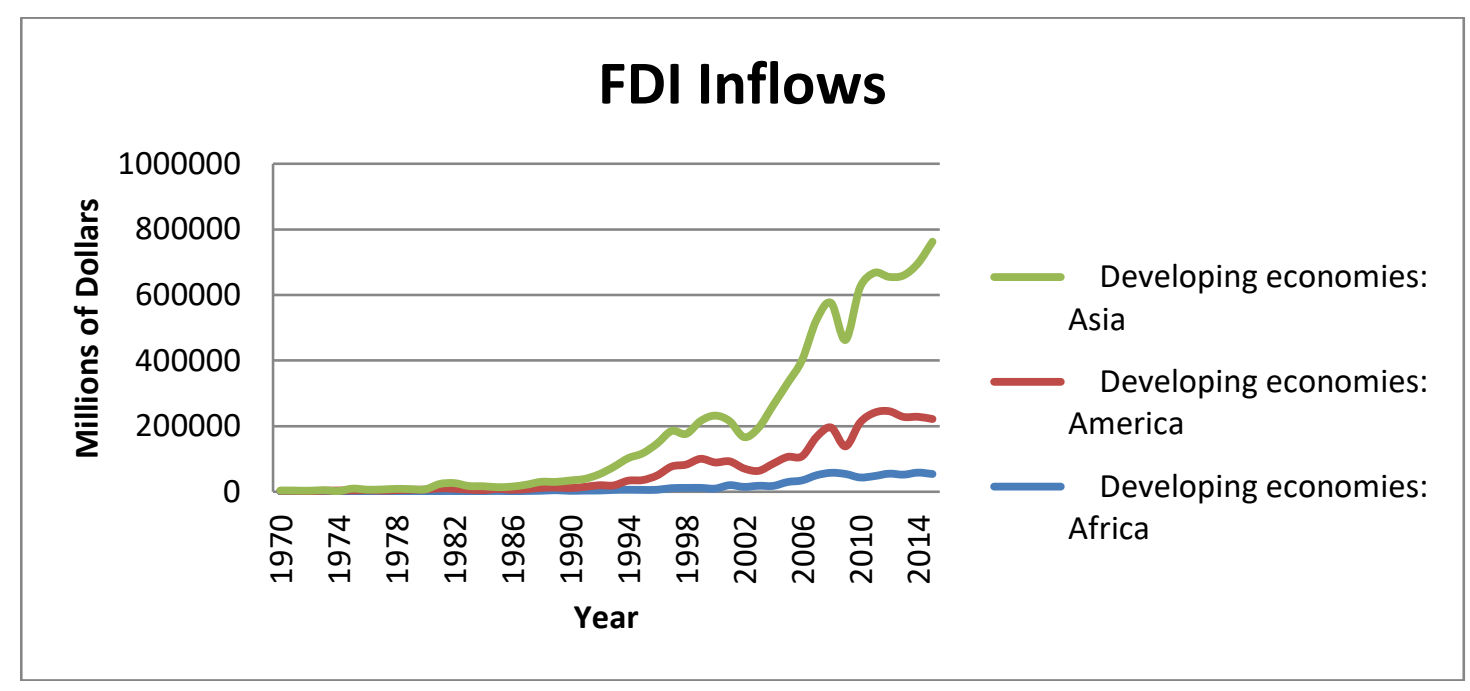

Source: UNCTAD 2017. 
From Figure 2 below, one can clearly see that total foreign direct investment is increasing in all the developing economies after 1980. The amount of FDI inflows into developing countries improved from 13 257 million dollars in 1970 to 589808 million dollars in 2002. Among developing countries, the distribution of world FDI inflow is uneven. Specifically, in 1970s, the flows of FDI to all the three regions were similar. During this year, FDI inflow to Asia was 854 million dollars, Africa 1267 million dollars and Latin America 1509 million dollars. The amount received by African countries stagnated in 1980 s while that of Latin America and Asia expanded impressively. Since then, Africa has fallen behind these regions in terms of FDI inflows. Even though most the other regions dominate Africa, there is an increasing trend in all the regions. The present situations show that the inward FDI flows to developing economies peaked, amounting to $\$ 681$ billion.

\section{Literature Review}

The impact of FDI and Trade openness on growth has broadly been studied empirically and theoretically in literature and the results are quite diverse and inconclusive. The findings in this area can be grouped into three categories. Those that concluded a positive relationship can be seen from the work of Heteş et al. (2009), Chang (2010), Asghar et al. (2011), Lean and Tan (2011), Zenasni and Benhabib (2013), Emmanuel (2014), Hussain and Haque (2016) and Chanie (2017). On the other hand, the paper that concluded negative relationship are, Mencinger (2003), Ahmed (2012), Saqib et al. (2013), Raičević et al. (2016), while few studies that have indicated inconclusive results are seen from the work of Lyroudi et al. (2004), Sukar et al. (2010), Javed et al. (2012), Mohamed et al. (2013) and Chowdhary and Kushwaha (2013) between FDI and growth.

The varied views indicates a literature gab indicate a gap, permitting us to develop more interest to further verify the growth-FDI relationship especially in SSA countries where few studies have been conducted. The paper will add to the existing literature recent data and the relationship between the above variables in multivariate form.

FDI impact on growth has broadly been studied empirically and theoretically with diverse and inconclusive results. Base on this varied views; researchers have developed more interest to further verify the growth-FDI relationship. There are numerous ways in which FDI profit the host country. This is observed through technological transfer (technological effects), resource transfer (resource transfer effects), creating of more jobs (employment effects) and improvement in the trade balance (balance of payment effects).

Letto-Gillies (2002) stated that foreign direct investment is essential to stimulate the growth of nations. For instance, when more capital, technology, knowledge and marketing skills are attracted to the economy through foreign direct investment channel, more productive materials are produced especially in situation where the capital are used efficiently (Sukar et al. 2010).

Even though couples of researches have shown the significant of FDI in stimulating growth, there is still some theoretical evidence stating that developing countries including SSA are not benefiting from FDI inflows. In some situation, foreign capital is transferred to the country to finance war or for consumption purposes, the benefit might not felt on the local population Krugman (2000). Considering the fact that there is no clear relationship between FDI and economic as stipulated by Emmanuel (2014), Akwaowo (2013), Doğan (2013), Zekarias (2016), Sukar et al. (2010) and Kamara (2013), we will review some few studies to verify the relationship between FDI and growth.

Emmanuel (2014) conducts a study to verify the impact of FDI on Economic Growth in CEMAC countries using panel data analysis. It was concluded that FDI impact Growth positively. Doğan (2013) investigates the causal effects of FDI on growth in Turkey using time series data analysis and the findings shows significant relationship between the two variables. It was recommended that more strategies should be initiated to attract more FDI to Turkey. For the case of Bangladesh, Hussain and Haque (2016) examines the effects of FDI and trade on economic growth using annual time series data for 1973 to 2014 and a similar result was obtained. 
For SSA countries fewer studies have been conducted and most of the studies support the view for the positive impact of FDI on growth. Sukar et al. (2010) verify the impact of FDI on economic growth in SSA using panel data analysis. It is indicated that FDI marginally impact growth with positive and significant effect. However, the author pointed that many other factors such as institutions and lack of strong macroeconomic stability limit the inflow of FDI to Sub Sahara Africa. Ndambiri et al. (2012) employs the generalized method of moments using panel data and the findings show similar result. On the other hand, few studies have indicated negative and inconclusive relationship between FDI and economic growth. Katerina et al. (2004) investigate the relationship between FDI and economic growth for transitional economies. Their results show insignificant relationship between the two variables and it was explained that further study should be conducted. A study conducted in Turkey by Demirsel et al. (2014) to verify the relationship between the above mentioned variables using monthly data for the period 2002:Q1 and 2014:Q1. Employing the Johansen test of cointegration, the author also came out with inconclusive results.

In modern world, countries are trading with one another considering the fact that international trade is mutually benefiting to everyone in society. Studies show that there is a positive relationship between trade openness and economic growth since it leads to increase productivities. However, some researchers view trade as being harmful, stating that large nations benefit most from trade by exploiting the smaller nations. For instance, India, often worry that opening their economies to international trade will lead to disaster because their industries won't be able to compete. Nketsiah and Quaidoo (2017) investigated the relationship between Foreign Direct Investment and Economic Growth using other control variables like inflation, gross fixed capital formation, trade openness and government spending by employing the time series data for the period 1983 to 2012 in Ghana. The results suggest that, the impact of foreign direct investment on economic growth in Ghana is significantly positive.

Nursini (2017) investigates the effect of fiscal policy and trade openness on economic growth in Indonesia for the period 1990 and 2015. The other concludes a positive and significant effect of trade openness on growth. It was recommended policies should be initiated by opening up Indonesia trade in other to achieve long term growth. Bayar (2016) looks at the impact of trade openness and economic freedom on economic growth using panel data for the European Union member states. A positive relationship was noted between trade openness and economic growth, showing that the impact of trade openness on growth relies on the ability of countries to develop their technology as well as infrastructures. Likewise, Ali and Abdullah (2015), Andersen and Babula (2008) and Mercan and Göçer (2013) pinpoint a positive relationship between trade openness and economic growth.

The causal effects between trade openness and economic growth have been verified intensively in literature. Saaed and Hussain (2015), Zeren and Ari (2013), Hatemi-J and Irandoust (2000), Yücel (2009) and Kar et al. (2014) investigate the causal effects between trade openness and economic growth and the findings show that trade openness have a positive and significant effect on growth. Ullah et al. (2014) investigated the relationship between domestic investment, foreign direct investment, and economic growth in Pakistan for the period 1976-2010. The findings pinpointed the existence of a long run relationship between foreign direct investment and economic growth. The direction of causality was investigated using Toda-Yamamoto techniques and the results showed that there exist a bidirectional causality between FDI and domestic investment, indicating the importance of FDI in stimulating Pakistan growth.

The effects of trade openness on economic might be controversial depending on the period the policy is taken. Faizal et al. (2013) states that a negative relationship might be obtain between trade openness and economic growth in the short run. The author emphasized trade policies should be initiated base on long term goals while Huchet et al. (2018) concludes that the effects of trade openness on growth depend on the type of goods that countries exports. Trade openness will negatively impact growth in situation where the good exported are of low qualities and positive in case high quality goods are traded. This implies that, the positive impact of trade openness on growth rely on the complexity of countries exports (Hidalgo and Hausmann, 2009). 
In modern world, FDI plays significant role in influencing nation's growth. The growth-FDI relationship as reviewed indicated that most of the authors employed the panel data analysis see Katerina et al.(2004), Sukar et al. (2010), Ndambiri et al. (2012), Doğan (2013) and Emmanuel (2014). On the other hand, few of the studies have used time series data analysis to verify the direction of causality between FDI and economic growth Doğan (2013), Ullah et al. (2014) and Can et al. (2017).

This paper was conducted, having as objective to examine the impact of FDI on SSA Growth, taking into consideration other control variable such as Trade Openness and inflation. The paper is similar to those in literature in terms of result and the methods. Panel data have been used and the results pinpointed that FDI positively impact growth. However, most past studies focus on the impact of FDI and trade openness on growth Emmanuel (2014), FDI and human capital on growth Azam and Ahmed (2015) and FDI, Physical capital and labor on growth Ahmed (2012). This paper is different in that we have looked at the combined effects of FDI, trade openness and inflation on economic growth. Nketsiah and Quaidoo (2017) employed similar variables but their paper is different in that they employed time series data.

\section{Data Source and Methodology}

The study focuses on the impact of FDI, trade openness and inflation on economic growth in Sub Saharan Africa, covering the period 2006 - 2015. The reason these variables are selected with the time setting, depends on data availability. All the variables are taken from World Development Indicator and are in real terms. Specifically, RGDP stand for real gross domestic product, RFDI is real foreign direct investment inflow, LRTO represent real trade openness (export+import/gdp) and RINFLA is real inflation (annual consumer prices \%). In some situations, the outcome is spurious and rendering the findings meaningless. This is due to the fact that researchers turn to omit the relevant variable(s), include unnecessary variable(s) or either adopt a wrongly functional form (Gujarati, 2004).

Therefore, the study uses 34 countries with a total of $(34 * 10=) 340$ observations, all the data are collected from World Development Indicators. In this study, the time dimension of ( $T=10)$ is smaller than the individual dimension $(\mathrm{N}=34)$ and for this reason, the traditional panel data approach is employed. Traditional panel data models are discussed in three basic categories. The first is the Pooled Ordinary Least Squares (POLS). In POLS, the effects of time and individuals dimensions are not important and panel data are used as a sample. The POLS model will be shown as demonstrated below:

$$
\mathrm{Y}_{\mathrm{it}}=\alpha+\beta \mathrm{X}_{\mathrm{it}}+\varepsilon_{\mathrm{it}}
$$

Where $\alpha$ is constant term of common effects, $\beta$ is slope parameters of common effects and $\varepsilon_{\mathrm{it}} \sim \mathrm{N}\left(0, \sigma_{\varepsilon}^{2}\right)$ is normally distributed error term.

Generally, it is unrealistic to assume that there is no individual effect in the model working with panel data. Therefore, the individual effect is examined in two different ways. The first is the Fixed Effects Model (FEM). In FEM, it is assumed that individual's effects are correlated with the independent variables in the panel data model. Therefore, the FEM is shown as follows:

$$
\mathrm{Y}_{\mathrm{it}}=\alpha_{\mathrm{i}}+\beta \mathrm{X}_{\mathrm{it}}+\varepsilon_{\mathrm{it}}
$$

Unlike in pooled model where $\alpha_{i}$ is a constant term, in the FEM in other to demonstrate the individual effects dummy variables are used. Therefore, the estimate of FEM is conducted by using the Least Squares Dummy Variables (LSDV). Using a great number of dummy variables in the model leads to many problems, especially, the problem of degrees of freedom. In case there is the problem of uncorrelated effects between the individuals and the independent variables, Random Effects Model (REM) is applied. This is demonstrated as shown below:

$$
Y_{i t}=\alpha_{i}+\beta X_{i t}+\varepsilon_{i t}
$$


Where $\alpha_{i}=\alpha+u_{i}$ and the individuals effects are regarded as a component of the random term. Then, the REM can be rewritten as follows:

$$
Y_{i t}=\alpha+\beta X_{i t}+w_{i t}
$$

Where $\mathrm{w}_{\mathrm{it}}=\mathrm{u}_{\mathrm{i}}+\varepsilon_{\mathrm{it}}$, and $\varepsilon_{\mathrm{it}} \sim \mathrm{N}\left(0, \sigma_{\varepsilon}^{2}\right), \mathrm{u}_{\mathrm{i}} \sim \mathrm{N}\left(0, \sigma_{\mathrm{u}}^{2}\right)$ and $\mathrm{w}_{\mathrm{it}} \sim \mathrm{N}\left(0, \sigma_{\varepsilon}^{2}+\sigma_{\mathrm{u}}^{2}\right)$ (Gujarati, 2004: 640-648).

Choosing the appropriate one from the POLS, FEM and REM models is an important step. For this purpose, despite the use of non-formal approaches, for this decision would be more accurate to follow the three-stage process. Tests are used to determine the appropriate model structure which contains the following steps: In the first stage, for us to decide between POLS and FEM, we use the Chow F-homogeneity test. If the null hypothesis is rejected, this means that the FEM is appropriate.

On the contrary, if the null hypothesis is non-rejected, POLS should be used. In the second stage, to make choice between POLS and REM, we use the LM-type tests (other study used Honda LM test). If the null hypothesis is rejected, this means that the REM model is valid. Failure to reject the null hypothesis means that the POLS models must be used. Finally, to choose between FEM and REM, we use the Hausman test. If the null hypothesis is rejected, it reached the conclusion that the FEM is the accurate one. Conversely, the null hypothesis is non-reject; REM will be the appropriate model.

\section{Empirical Results}

In other to determine the effects of Foreign Direct Investment, Trade Openness and Inflation on Economic growth, specification tests are needed. Table 2 gives the specification test results for SSA countries.

Table 2. Specification Tests Results

\begin{tabular}{|c|c|c|c|}
\hline SELECTED MODEL & CHOW $F$ & HONDA LM & HAUSMAN CHI-SQUARE \\
\hline REM & $878.9645^{\mathrm{a}}$ & $37.6514^{\mathrm{a}}$ & 3.7254 \\
\hline
\end{tabular}

Note: a significant at $1 \%$.

Source: Author calculation.

The Chow $\mathrm{F}$ test in Table 2 is statistically significant at $1 \%$ significance level. This test result indicates that the FEM is preferred compare to the POLS. The calculated Honda LM statistics is significant at $1 \%$ level indicating that we have to choose the REM versus POLS. In this case, both Chow-F and Honda LM statistics results shows individual affects are valid for SSA countries. In the last step of test, the REM versus FEM with Hausman Chi-Square test is tested. The calculated chi-square value is statistically insignificant. Therefore, the null hypothesis cannot be rejected. As shown in Table 2, the REM is determined to be more appropriate for countries of SSA. In other words, the Hausman's test indicates that the REM is preferable to the FEM. Here; the validity of the REM is consistent with previous studies.

Table 3. Test Results of the Econometric Assumptions

\begin{tabular}{|c|c|c|c|c|c|c|c|}
\hline \multicolumn{2}{|c|}{$\begin{array}{c}\text { CROSS SECTIONAL } \\
\text { DEPENDENCE }\end{array}$} & \multicolumn{2}{c|}{ AUTOCORRELATIONS } & \multicolumn{3}{c|}{ HETEROSCEDASTICTY } \\
\hline Friedman & Frees & Pesaran & LM & LM5 & LBF_WO & LBF_W10 & LBF_W50 \\
\hline $256.656^{\mathrm{a}}$ & $17.453^{\mathrm{a}}$ & $50.349^{\mathrm{a}}$ & $6.640^{\mathrm{b}}$ & $1417.63^{\mathrm{a}}$ & $3.7966^{\mathrm{a}}$ & $3.6276^{\mathrm{a}}$ & $2.7994^{\mathrm{a}}$ \\
\hline
\end{tabular}

Note: ${ }^{a}$ significant at $1 \%$ and ${ }^{b}$ significant at $5 \%$.

Source: Author calculation. 
After determining the appropriate model structures, we proceeded with the estimation process. However, the estimation results of the panel data can be used only when the econometric assumptions are satisfied. Therefore, after the analysis, the estimation must be applied on cross sectional dependence, autocorrelations, and heteroscedasticity. The results of these tests are given in Table 3.

The test results in Table 3 show that the estimated error of the models for all the tests pinpoints deviation from the econometric assumptions. Thus, standard REM estimates are consistent, but they are not efficient, showing that the estimated standard error is biased. Namely, the predicted results would not be appropriate to use in this state. In this case, the model must be estimated using a new method in other to obtain result with the standard errors that minimizes these problems. In this approach, the standard errors are weighed according to the panel. Thus, the new standard errors are consistent and robust to econometrical problems such as cross-sectional dependence, autocorrelations, and heteroscedasticity. The robust estimation results of panel data models are given in Table 4.

Table 4. Panel Estimation Results with Robust Standard Errors

\begin{tabular}{|l|c|c|c|l|}
\hline $\begin{array}{l}\text { Dependent Variable: } \\
\text { RGDP }\end{array}$ & Constant & RFDI & RTO & RINFLA $^{\text {Coefficients }}$ \\
\hline $15.7740^{\mathrm{a}}$ & $0.0028^{\mathrm{c}}$ & $3.7871^{\mathrm{a}}$ & $-5.48 \mathrm{e}-06^{\mathrm{a}}$ \\
\hline Robust Standard Errors & 1.4215 & 0.0015 & 0.7302 & $9.66 \mathrm{e}-07$ \\
\hline Z-Statistics & 11.0967 & 1.9198 & 5.1864 & -5.6729 \\
\hline S.E. of Regression & 0.1300 & Sum Squared Resid & 5.6992 & \\
\hline $\mathbf{R}^{\mathbf{2}}$ & 0.2521 & Wald-F Statistics & $107575.10^{\mathrm{a}}$ & \\
\hline
\end{tabular}

Note: ${ }^{\text {a }}$ significant at $1 \%$ and ${ }^{\mathrm{b}}$ significant at $5 \%$.

Source: Author calculation.

The estimated results in Table 4 reveal that the signs of all estimated coefficients parameters are appropriate with expected sign as in econometric literature. The coefficients are significant at the $1 \%$ level. The estimated coefficient for foreign direct investment is significant at the \%10 level. In addition, the standard error of regression and the sum of squared resid are relatively small. Calculated F-statistics pinpointed that the estimated model is generally significant or that the model fits very well. However, by looking into each model in detail, the following conclusions were reached.

In Table 4, although FDI variable is statistically significant at $10 \%$, the test statistic value is approximately 1.92 . That is, the value is very close to $5 \%$ level of significant. This implies that Economic Growth positively impact Foreign Direct Investment for SSA Countries. The sign of all the parameters are compatible with previous literatures like the work of Sukar et al. (2010), Zekerias (2016), and Yalçınkaya and Aydın (2017).

FDI inflows to developing countries have increased significantly since the 1980s. Among developing countries, the distribution of FDI inflows has been uneven. In an effort to attract FDI and spur economic growth, many developing countries including Sub-Sahara African countries have established investment agencies and have introduced policies that include fiscal and financial incentives. Even though such polices can be effective in attracting foreign investment, the potential benefit that FDI bring to host countries could be limited.

In this paper we used panel data to examine the effect of FDI on economic growth of selected SSA countries over the 2006-2015 periods. The estimation results indicate that the effect of FDI on economic growth is positive $(0.0028)$ and it is statistically significant at $10 \%$. This finding is similar to that of Rodrick (1999), Aitken and Harrison (1999) and Sukar et al. (2010), where it is argued that the effect of FDI on economic growth is weak. The estimated trade openness parameter is 3.7871 and statistically significant at 
$1 \%$ level. This result illustrates that if there is a $1 \%$ increase in SSA trade openness, economic growth rises by $3.7874 \%$. This Result is also in line with that of Yanikkaya (2003), Sukar et al. (2010), and Keho (2017). Therefore, it can be said that an outward-looking growth policy is suitable for SSA countries. In other words, SSA countries are outward-oriented economies.

Lastly, the estimated inflation coefficient is statistically significant at $1 \%$ level and the sign of the parameter is negative as expected. But the size of the parameter is close to zero (-5.48e-06). According to this result, if inflation rate decrease by $1 \%$, economic growth of SSA countries will increase. Although, previous studies designate different results by looking at the relationship between inflation and economic growth, the majority of literature indicates that there is a negative relationship between the two variables. In that case, our empirical results highly support the view of a negative relationship between inflation and economic growth.

The bases for the negative relationship between inflation-economic growths can be explained as follows: (1) Inflation causes negative expectations and ambiguities about the future, which affects investments and growth in the negative direction. (2) Due to the high inflation, the sub-prices of different sectors are increasing at different rates, affecting the distribution of resources negatively. (3) Inflation causes the national currency to appreciate and ultimately exports are adversely affected (Pyndick and Solimano (1993), Berber and Artan (2004), Yapraklı (2007)). That is, economic growth in SSA countries depends mostly on diminish inflation rate, having the objective to stabilize the prices of goods and services.

\section{Conclusion}

This paper is conducted to verify the relationship amongst foreign direct investment, trade openness, inflation and economic growth in SSA countries. The result shows that trade openness, FDI and inflation are significant in explaining the SSA growth.

Specifically, foreign direct investment and trade openness positively impact growth except inflation. The positive impact of FDI on growth implies that as it increases, more capital, jobs and technology will be transferred to SSA. Based on our findings, it is recommended that SSA countries should develop strategies that will draw additional foreign direct investment to Africa. This could be achieved through exports diversification, creation of favorable business climate and the development of macroeconomic policies that would encourage economic openness and infrastructural development.

Moreover, lack of accountability and efficient management of resources often characterizes the SSA countries, making the citizen not to feel the positive impact from FDI. Thus it should be made as policy to properly monitor FDI-utilizing projects. This will reduce the mismanagement and misutilization of the foreign resources and will be equitably distributed. This will go a long way to reduce poverty, unemployment and income inequality.

In addition, SSA should not just focus on trade by exporting purely primary and raw material which consist of low qualities from agriculture and oil resources. The government should aim in diversifying the sector through industrialization and the export of semi -finished and finished products. In doing so, more capital will flow to Africa in the form of FDI. What Africa is doing is that, least complex products are exported to countries like China. These products are being transformed and made more complex and then exported back to Africa at high price. This explains the reason why China grows more rapidly than Africa.

Above all, the significant impact of trade openness on growth indicates that major should be taken by the government to increase international trade and the level of inter-regional trade. This will increase the rate of technical progress, efficiency and productivity in growth among the SSA through the expansion in output and through the market. Inflation was taken as macroeconomic variable and is significant in explaining the SSA growth. Thus strong macroeconomic policies should be adopted by the government in minimizing the level of inflation, since the findings indicate a negative impact of inflation on growth. 


\section{References}

Ahmed, E. M. (2012). Are the FDI inflow spillover effects on Malaysia's economic growth input driven?. Economic Modelling, 29(4), 1498-1504. http://doi.org/10.1016/j.econmod.2012.04.010

Aitken, B., \& Harrison, A. E. (1999). Do domestic firms benefit from direct foreign investment? Evidence from Venezuela. The American Economic Review, 89(3), 605-618.

Akwaowo, E. (2013). Exploring foreign direct investments in developing african countries : their effects on the economic growth in Cameroon (2006-2011). Business \& Economics, 5(1), 18-35.

Ali, W., \& Abdullah, A. (2015). The impact of trade openness on economic growth of Pakistan: 1980-2010. Global Business and Management Research: An International Journal, 7(2), 120-129.

Andersen, L., \& Babula, R. (2008). The link between openness and long-run economic growth. Journal of International $\begin{array}{llll}\text { Commerce } \quad \text { and } & \text { Rconomics, } & \text { Retrieved }\end{array}$ http://66.7.151.178/publications/332/journals/openness_growth_link.pdf.

Asghar, N., Nasreen, S., \& Rehman, H. (2011). Relationship between FDI and economic growth in selected Asian countries: A panel data analysis. Review of Economics \& Finance, 2, 84-96.

Azam, M., \& Ahmed, A. M. (2015). Role of human capital and foreign direct investment in promoting economic growth. International Journal of Social Economics, 42(2), 98-111. http://doi.org/10.1108/IJSE-05-2014-0092

Bayar, Y. (2016). Impact of openness and economic freedom on economic growth in the transitional economies of european union. South-Eastern Europe Journal of Economics, 1, 7-19.

Berber, M., \& Artan, S. (2004) .Türkiye'de enflasyon-ekonomik büyüme ilişkisi: Teori-literatür ve uygulama. Atatürk Üniversitesi iiBF Dergisi, 18(3-4), 103-117.

Can, M., Doğan, B., \& Değer, O. (2017). The Relationship between research \& development investment expenditure, foreign direct investment and economic growth. Journal of Applied Economic Sciences, 12(1), 58-62.

Chang, S. C. (2010). Estimating relationships among FDI inflow, domestic capital, and economic growth using the threshold error correction approach. Emerging Markets Finance and Trade, 46(1), 6-15. http://dx.doi.org/10.2753/REE1540-496X460101

Chanie, M. (2017). Effect of foreign direct investment on economic growth in ethiopia : an empirical investigation. International Journal of Current Research, 9(9), 58301-58306. Retrieved from http://theglobaljournals.com/paripex/file.php?val=November_2012_1353430209_c1e2b_09.pdf

Chowdhary, R., \& Kushwaha, V. (2013). Domestic investment, foreign direct investment and economic growth in India since economic reforms. Journal of Transformative Entrepreneurship, 1(2), $74-82$. http://dx.doi.org/10.14239/JTE.2013.01201

Demirsel, M. T., Öğüt, A. \& Mucuk, M. (2014). The effect of foreign direct investment on economic growth: The case of Turkey. 01-04 September 2014, 12th International Academic Conference, Prague, 312-321.

Doğan, E. (2013). Foreign direct investment and economic growth: A time series analysis of Turkey: 1979-2011. Çankırı Karatekin University Journal of the Faculty of Economics and Administrative Sciences, 3(2), 239-252.

Emmanuel, O. N. B. (2014). Foreign direct investment and economic growth: The experience of cemac countries. Journal of Finance \& Economics, 2(1), 1-14. http://doi.org/10.12735/jfe.v2i1p1

Faizal, P. R. M., Ridhwan, A. A. M., \& Kalsom, A. W. (2013). The Entrepreneurs characteristic from al-Quran and al-Hadis. International Journal of Trade, Economics and Finance, 4(4), 191-196. http://doi.org/10.7763/IJTEF.2013.V4.284

Gujarati, D. (2004). Basic econometric (4th edn.). USA: The McGraw-Hill Company.

Hatemi-J, A., \& Irandoust, M. (2000). Export performance and economic growth causality: An empirical analysis. Atlantic Economic Journal, 28(4), 412-426. Retrieved from http://link.springer.com/article/10.1007/BF02298394.

Heteş, R., Moldovan, N., \& Miru, O. (2009). Foreign direct investments and economic growth in Central and Eastern European countries. Megatrend Review: The International Review of Applied Economics, 6(2), 239-252.

Hidalgo, C., \& Hausmann, R. (2009). The building blocks of economic complexity. Proceedings of the National Academy of the Sciences of the United States of America, 106(26), 10570-10575. http://doi.org/10.1073/pnas.0900943106

Huchet-Bourdon, M., Mouël, C. L., \& Vijil, M. (2018). The relationship between trade openness and economic growth: Some new insights on the openness measurement issue. World Economy, 41(1), 59-76. http://doi.org/10.1111/twec.12586 
Hussain, M. E., \& Haque, M. (2016). Foreign direct investment, trade, and economic growth: An empirical analysis of Bangladesh. Economies, 4(7), 1-14, http://doi.org/10.3390/economies4020007

Letto-Gillies, G. (2002). Hymer, the nation-state and the determinants of multinational corporations' activities. Contributions to Political Economy, 21(1), 43-54.

Javed, K., Sher, F., Awan, R. U., \& Ashfaq, M. (2012). Foreign direct investment, trade and economic growth: A comparison of selected South Asian countries. International Journal of Humanities and Social Science, 2(5), 210220.

Kamara, Y. U. (2013). Foreign direct investment and growth in Sub-Saharan Africa what are the channels?. Working Paper University of Kansas, 1-29.

Kar, M., Nazlıoğlu, S., \& Ağır, H. (2014). Trade openness, financial development, and economic growth in Turkey: Linear and nonlinear causality analysis. Journal of BRSA Banking and Financial Markets, 8(1), 63-86.

Katerina, L., John, P., \& Athanasios, V. (2004). Foreign direct investment and economic growth in transition economies. South Eastern Europe Journal of Economics, 1, 97-110. http://doi.org/10.1080/00036840701579176

Keho, Y. (2017). The impact of trade openness on economic growth: The case of Cote d'Ivoire, Cogent Economics \& Finance, 5(1), 1-14.

Krugman, P. (2000). Fire-sale FDI. University of Chicago Press, Capital flows and the emerging economies: Theory, evidence, and controversies. 43-58.

Lean, H. H., \& Tan, B. W. (2011). Linkages between foreign direct investment, domestic investment and economic growth in Malaysia. Journal of Economic Cooperation \& Development, 32(4), 75-96.

Mencinger, J. (2003). Does foreign direct investment always enhance economic growth? Kiyklos, 56(4), 491-508.

Mercan, M., \& Göçer, İ. (2013). The effect of financial development on economic growth in BRIC-T countries: Panel data analysis. Journal of Economic and Social Studies, 3(1), 199-216. http://doi.org/10.5539/ijef.v6n11p72

Mohamed, M. R., Singh, K. S. J., \& Liew, C. Y. (2013). Impact of foreign direct investment \& domestic investment on economic growth of Malaysia. Malaysian Journal of Economic Studies, 50(1), 21-35.

Ndambiri H. et al. (2012). Determinants of economic growth in Sub-Saharan Africa: A panel data approach. International Journal of Economics and Management Sciences, 2(2), 18-24.

Nketsiah, I., \& Quaidoo, M. (2017). The effect of foreign direct investment on economic growth in Ghana. Journal of Business and Economic Development, 2(4), 227-232. http://doi.org/10.11648/j.jbed.20170204.14

Nursini, N. (2017). Effect of fiscal policy and trade openness on economic growth in Indonesia: 1990-2015. International Journal of Economics and Financial Issues, 7(1), 358-364. Retrieved from http:\%0Awww.econjournals.com

Pyndick, R. S., \& Solimano, A. (1993). Economic instability and aggregate investment. NBER Working Paper Series, 1-55.

Raičević, B., Ignjatijević, S., \& Milojević, I. (2016). Financial analysis of foreign direct investment on economic growth of developing countries. Economics of Agriculture Review Paper, 2, 649-664.

Rodrick, D. (1999). The new global economy and developing countries: Making openness work. Washington DC: Overseas Development Council (ODC) Policy Essay No. 24.

Saaed, A. A. J., \& Hussain, M. A. (2015). The causal relationship among trade openness, financial development and economic growth: Evidence from Kuwait. Journal of Emerging Issues in Economics, Finance and Banking, 4(1), 1385-1413.

Saqib, N., Masnoon, M., \& Rafique, N. (2013). Impact of foreign direct investment on economic growth of Pakistan. Advances in Management \& Applied Economics, 3(1), 35-45.

Sukar, A., Ahmed, S., \& Hassan, S. (2010). The Effects of foreign direct investment on economic growth: The case of SubSahara Africa. Southwestern Economic Review Economic, 34, 61-74.

Ullah, I., Shah, M., \& Khan, F. U. (2014). Domestic investment, foreign direct investment, and economic growth nexus: A case of Pakistan. Economics Research International, 2014, 1-5. http://doi.org/10.1155/2014/592719

World Development Indicators, https://data.worldbank.org/products/wdi

Yalçınkaya, Ö., \& Aydın, H. I. (2017). Doğrudan yabanci sermaye yatirimlarinin ekonomik büyüme üzerindeki etkileri: Seçili yükselen piyasa ekonomileri örneği (1992-2015). Ağrı İbrahim Çeçen Üniversitesi Sosyal Bilimler Enstitüsü Dergisi, 3(1), 39-64.

Yanıkkaya, H. (2003). Trade openness and economic growth: A cross-country empirical investigation. Journal of Development Economics, 72(1), 57-89. 
Yapraklı, S. (2007). Enflasyon ve ekonomik büyüme arasindaki ilişki: Türkiye için eş-bütünleşme ve nedensellik analizi. Atatürk Üniversitesi Sosyal Bilimler Enstitüsü Dergisi, 10(2), 287-301.

Yücel, F. (2009). Causal relationships between financial development, trade openness and economic growth: The case of Turkey. Journal of Social Sciences, 5(1), 33-42.

Zekarias, S. M. (2016). The impact of foreign direct investment (fdi) on economic growth in Eastern Africa: Evidence from panel data analysis. Applied Economics and Finance, 3(1), 145-160. http://doi.org/10.11114/aef.v3i1.1317

Zenasni, S., \& Benhabib, A. (2013). The determinants of foreign direct investment and their impact on growth: Panel data analysis for AMU countries. International Journal of Innovation and Applied Studies, 2(3), 300- 313.

Zeren, F., \& Ari, A. (2013). Trade openness and economic growth: A panel causality test. International Journal of Business and Social Science, 4(9), 317-324. http://www.ijbssnet.com/journals/Vol_4_No_9_August_2013/32.pdf 